\title{
O RESGUARDO APÓS O NASCIMENTO
}

Paulo César Kuhânĩpi Xerente
Professor Alfabetizador

Armando Sõpre Xerente

Professor Alfabetizador

Jurandi Souza Xerente

Professor Alfabetizador

\section{ROWASKUKTURÊ}

Akwẽ sĩ pikõ krapre pari zatô romkmãdâ dasa nãhã tmã tuirê, are pikõi mã si kõdi tô ambâ mã zemã. Pikõ krapre apri zatô 8 (oito) nã bdâ kripra nãmr watbro knã, mãrĩ dure tê kmãkwamãr kõ snã piza tê kahri kõd siwakru dasa tê kmẽsi kõdi. Tô tanẽ dure ambâ siwakru mãrĩ tê krnẽ kõdi are dure siwakru krmõr kõdi rowaste mba are dure mãrĩ tê kmãdâ kõdi, tanẽ wa zatô aiktepre krsdari nẽsi têsizai wa. Are ĩsaze tô kupazu, kupa, kumdi, karo kãtô tbê ĩhâi nẽhã tbê ĩhãi kõnẽ hã tê krnẽ kõdi pikõ krapre pari romkra zatô dure ĩpsê nẽhã si krẽ.

PALAVRAS-CHAVE: Akwẽ nĩm romkmãdâ; pikõ; pikõi krapre kripra smrãre.

\section{RESUMO}

O povo Akwẽ tem o costume de resguardar o nascimento da criança. A mulher, durante os oito dias, não sai de casa e não pode cozinhar. O homem não pode sair na floresta e não pode fazer esforços físicos e nem ter relação sexual com outra mulher. E ambos não podem comer algumas espécies de peixes, carnes de caça e nem algumas frutas. Podendo comer farinha branca, tapioca, batata-doce, mandioca e arroz.

PALAVRAS-CHAVE: cultura akwẽ; mulher; reguardo. 
O povo Akwẽ tem o costume de guardar e respeitar após o nascimento de um bebê para crescer sadio sem adoecer, ou seja, espiritualmente forte.

Durante o tempo de resguardo, após o nascimento de uma criança Akwẽ, a mulher tem oito dias para ficar dentro de um quarto bem fechado. Ela não pode sair em céu aberto, toma banho dentro de casa. Isso não diferencia o sexo, o resguardo é a mesma coisa para um bebê menino ou menina.

$\mathrm{E}$, quando a criança nascer, tem esse mesmo processo de resguardo, que serve para esposa e marido. A esposa tem que evitar algumas carnes de caça e alimentação. Os Akwẽ já têm a receita própria para o momento do parto, ou seja, para resguardo.

A mulher não pode cozinhar no fogão e não pode comer peixe de couro, como exemplo, jaú, também evita alguns frutos, por exemplo, manga, mamão etc. A recomendação para a mulher e o marido comer é a farinha de mandioca branca ou tapioca, arroz, batata doce.

A recomendação para o homem durante o resguardo é quase o mesmo procedimento da esposa. O homem não pode fazer muita força e não pode andar muito, não pode ver bichos dos matos, porque faz mal para um bebê Akwẽ recém-nascido, segundo pajé, que aparece para o bebê e começa chorar. Isso tudo é durante os oito dias após nascimento de uma criança. $\mathrm{O}$ pai não pode fazer relação sexual com outra mulher. Se fizer a barriga do bebê enche, começa a chora, e não pode comer coisa assada.

Essas são receitas de resguardo de um bebê Akwẽ recémnascido tanto para a mulher quanto para o homem. Esse resguardo tem que ser obedecido na cultura do povo Akwẽ. 